\title{
ANALISA PEMILIHAN SUPPLIER RAMAH LINGKUNGAN DENGAN METODE ANALYTICAL NETWORK PROCESS (ANP) PADA PT KIMIA FARMA PLANT SEMARANG
}

\author{
Nia Budi Puspitasari ${ }^{*}$, Khairunnisa Hanan Yancadianti \\ Jl. Prof. Soedarto, SH, Kampus Undip Tembalang, Semarang, Indonesia
}

\begin{abstract}
Abstrak
Indonesia bersama Thailand dan Filipina menguasai pasar industri farmasi Asia Tenggara sebesar $80 \%$ serta diperkirakan pasar industri farmasi hingga 2016 akan mencapai nilai 96,1 miliar USD. Dalam menghadapi hal tersebut diperlukan beberapa hal dimana pada saat ini isu mengenai lingkungan sangat menjadi tren masyarakat. Regulasi pemerintah kepada industri mengenai lingkungan dan peningkatan jumlah masyarakat yang beralih kepada green product membuat industri untuk mulai memasukkan aspek lingkungan ke dalam proses industrinya. Pemilihan pemasok merupakan masalah pengambilan keputusan penting agar mendapatkan pemasok yang dapat meningkatkan daya saing perusahaan. Kriteria pemilihan pemasok umumnya hanya didasarkan pada aspek cost, delivery, dan kualitas. Hal tersebut belum sesuai dengan isu lingkungan dan regulasi pemerintah saat ini. Pemilihan green supplier dilakukan pada PT Kimia Farma plant Semarang. Hal tersebut dilakukan karena PT Kimia Farma plant Semarang berkeinginan mengarahkan produk yang dihasilkan ke arah green product. Saat ini PT Kimia Farma plant Semarang mengalami penurunan produksi dalam 2 tahun terakhir dimana pada jangka 5 tahun, PT Kimia Farma melakukan pergantian supplier sebanyak 5 kali. Analisa pemilihan green supplier tersebut dilakukan menggunakan metode Analytichal Network Process (ANP) karena ANP merupakan salah satu metode yang mampu merepresentasikan tingkat kepentingan berbagai pihak dengan mempertimbangkan saling keterkaitan antar kriteria dan sub kriteria yang ada. . Pada pemilihan green supplier kriteria kualitas memiliki bobot 0,369, kriteria lingkungan memiliki bobot sebesar 0,246, kriteria harga memiliki bobot 0,159 , kriteria pengiriman 0,11 kriteria pelayanan 0,072 , dan kriteria hubungan pemasok 0,044. Rekomendasi supplier yang diberikan adalah PT Sejong karena memiliki bobot terbesar yaitu 0,271 .
\end{abstract}

Kata Kunci : lingkungan; supplier; ANP; keterkaitan

\begin{abstract}
Indonesia with Thailand and Philippines now lead pharmaceutical industry market of sotheast asia by $80 \%$ yet pharmaceutical industry market is predicted to reach 96.1 billion US dollars by 2016. To deal with it, need to notice environmental issue which is be a trend in our society. Government's regulation of industry about environment and growth of people who switch to green product make industries begin to notice environment aspect in their industrial process. The decision in supplier selection will be very important in order to get suppliers who can improve competitiveness of the company. The criteria selection of supplier generally based only on aspect of cost, delivery, and quality. It is not appropriate with environmental issue and current government regulation. Green supplier selection is done in the PT Kimia Farma Plant Semarang because their sales are decline in the last two years which I period of 5 years, PT Kimia Farma had changed their supplier much as 5 times. Selection analysis of those green supplier is done by using Analytichal Network Process (ANP) methode because it is one of methode which can represents the level of interestd of various parties by consider relation between cryteria and subcryteria available. In green supplier selection, quality criteria weighs 0,369, environment criteria weighs 0,246, cost criteria 0,159, delivery criteria 0,11, and service criteria 0,072. The recommended supplier given is PT Sejong because it has the greatest weight of 0,268.
\end{abstract}

Keyword : enviroment; supplier; ANP; independence

\footnotetext{
${ }^{*}$ Penulis Korespondensi.

email: niabudipuspitasari@gmail.com
} 


\section{Pendahuluan}

Seiring dengan berkembangnya industri industri yang ada, beberapa tahun belakangan ini kepedulian konsumen terhadap lingkungan hidup semakin meningkat dari hari ke hari. Sebagian konsumen yang selalu selektif dalam membeli produk demi menyokong kelangsungan hidup dikenal dengan nama green consumer (Ferraro, 2009). Green supply chain mangement sebagai proses menggunakan input yang ramah lingkungan dan mengubah input tersebut menjadi keluaran yang dapat digunakan kembali pada akhir siklus hidupnya sehingga menciptakan rantai pasok yang berkelanjutan (Penfield, 2007). Green supply chain management melibatkan praktek praktek tradisional manajemen rantai pasok, yang mengintegrasikan kriteria lingkungan, atau masalah pembelian barang atau jasa dan hubungan jangka panjang dengan pemasok (Gilbert, 2000). Dari beberapa unsur tersebut pembelian barang dan hubungan jangka panjang kepada pemasok merupakan hal yang penting dalam penerapan green supply chain management.

Menurut Samadhan (2013), salah satu faktor kesuksesan sebuah perusahaan adalah pemilihan pemasok. Pemilihan pemasok yang tepat dapat menjamin ketersediaan bahan baku untuk menjaga lintasan produksi. Menurut Ghoddsypour dan O'Brien (2001) pemilihan pemasok merupakan masalah pengambilan keputusan penting agar mendapatkan pemasok yang dapat meningkatkan daya saing perusahaan. Permasalahan yang muncul adalah ketika menentukan alternatif supplier menjadi semakin kompleks seiring dengan tuntutan konsep green supply chain management. Kriteria pemilihan pemasok adalah meliputi harga, kualitas, pengiriman, teknologi, fleksibilitas, budaya, inovasi, dan hubungan dengan pemasok (Amin dan Zhang, 2012). Aspek tersebut sudah tidak sesuai lagi dengan tuntutan regulasi pemerintah UU RI No. 05 Tahun 1984 pasal 3 mengenai perhatian terhadap lingkungan hidup dan peningkatan kesadaran masyarakat akan pentingnya perlindungan lingkungan oleh karena itu muncul-lah konsep green supplier selection yaitu penerapan pemilihan supplier yang mempertimbangkan aspek lingkungan didalamnya.

PT KF memproduksi barang sesuai dengan hasil pemesanan dimana dalam 2 tahun terakhir PT KF mengalami penurunan produksi. Data produksi dalam 5 tahun terakhir dapat dilihat pada tabel 1.

Tabel 1. Jumlah Total Produksi Kosmetik PT KF

\begin{tabular}{ccc}
\hline Periode & Total Produksi & $\begin{array}{c}\text { Selisih dari Tahun } \\
\text { Sebelumnya }(\%)\end{array}$ \\
\hline 2010 & 56.245 .324 .150 & - \\
2011 & 59.652 .357 .246 & 6,06 \\
2012 & 75.680 .240 .367 & 26,86 \\
2013 & 65.869 .268 .170 & $-12,96$ \\
2014 & 60.245 .723 .250 & $-8,53$ \\
\hline
\end{tabular}

Sumber : Data Produksi PT Kimia Farma

Jurnal Teknik Industri, Vol. XI, No. 1, Januari 2016
Menurunya jumlah produksi ini menunjukkan peminat dari produk kosmetik PT KF di pasar sudah menurun. Jika tidak diambil langkah lebih lanjut dalam kurun waktu beberapa tahun ke depan maka sangat memungkinkan produk kosmetik PT KF tidak dapat bersaing di pasar. Oleh karena itu, untuk dapat meningkatkan jumlah produksi dan tetap dapat bersaing pada pasar kosmetik PT KF perlu melakukan inovasi dengan memenuhi pasar dengan tetap tidak menggunakan produk yang berbahaya dan sudah memperhatikan aspek lingkungan.

Dalam pembelian kemasan bedak marcks tersebut PT KF sudah menjalankan kerjasama kepada beberapa supplier, namun kerja sama tersebut tidak berlangsung cukup lama yang diakibatkan oleh beberapa faktor, hal tersebut dapat dilihat dalam Tabel 2.

Tabel 2. Data Supplier Kontainer Bedak Marcks

\begin{tabular}{ll}
\hline \multicolumn{1}{c}{ Supplier } & \multicolumn{1}{c}{ Peroide } \\
\hline PT Ratna Baru & Oktober 2011 - April 2013 \\
PT Triple Five & $\begin{array}{l}\text { November 2011 - Desember } \\
\text { 2012 }\end{array}$ \\
PT Asia Plastik & Desember 2011 - Maret 2013 \\
PT Tunggal & Januari 2013 - Desember 2013 \\
Jaya & Januari 2013 - Desember 2014 \\
PT Java Plastik & PT Indomulti \\
Plasindo & September 2014 - Sekarang \\
PT Sentosa & Agustus 2014 - Sekarang \\
Jaya &
\end{tabular}
Sumber : Data Supplier PT KF

Berdasarkan data pada Tabel 2 dapat kita lihat bahwa dalam jangka waktu 4 tahun terakhir PT KF bekerja sama dengan pemasok cukup singkat, dimana jangka waktu paling lama yaitu 1 tahun 6 bulan. Pada bulan Januari 2014 - Juli 2014 PT KF hanya bekerja sama dengan 1 pemasok yaitu PT Java Plastik, dimana hal tersebut tidak sesuai dengan sertifikasi ISO 9000 yang telah didapat oleh PT KF yaitu setiap perusahaan bekerja sama minimal dengan 2 perusahaan untuk dalam jangka waktu yang sama dan dengan produk yang sama.

Menurunnya jumlah produksi ini menunjukkan peminat dari produk kosmetik Kimia Farma di pasar sudah menurun. Dimana kesadaran masyarakat mengenai isu kerusakan lingkungan hidup cukup besar, kesadaran tersebut membuat konsumen untuk memilih produk yang ramah lingkungan. Hal ini sesuai dengan penelitian Ferraro (2009) juga mengatakan bahwa 6 dari 10 konsumen di Amerika lebih memilih untuk membeli green product dari pada produk - produk biasa. Pembuatan produk yang ramah lingkungan berasal dari bahan baku yang juga ramah lingkungan. Dimana untuk mendapatkan bahan baku yang ramah lingkungan, diperlukan supplier yang juga sudah menerapkan ramah lingkungan dalam proses produksinya. 
Penelitian ini ditujukan untuk mengidentifikasi kriteria - kriteria dan sub kriteria - subkriteria yang dikategorikan sebagai green supplier selection pada PT Kimia Farma plant Semarang, mengidentifikasi bobot kepentingan (weight) pada setiap kriteria dan sub kriteria, memberikan rekomendasi alternatif supplier yang memenuhi konsep green supplier selection dengan metode ANP (Analytical Network Process). ANP merupakan salah satu metode yang mampu merepresentasikan tingkat kepentingan berbagai pihak dengan mempertimbangkan saling keterkaitan antar kriteria dan sub kriteria yang ada (Vanany, 2003).

\section{Tinjauan Pustaka}

\section{Green Supply Chain Management}

Vachon dan Klassen (2006) mengatakan bahwa melalui interaksi antara supplier dan konsumen, perusahaan dapat mendirikan dan mempraktekan sebuah program solusi yang efektif, ketika menghadapi tantangan isu lingkungan. Dari eksplorasi pada industri printing di Kanada dan Amerika, diketahui bahwa melakukan kerjasama mengenai green scheme dengan demikian supplier memperlihatkan pengaruh positif pada waktu pengiriman, sedangka pada konsumen memperlihatkan pengaruh positif yang berkualitas, fleksibilitas, dan perlindungan lingkungan. Kainuma dan Tawara (2006) mengatakan bahwa USA mengeluarkan buku pandungan yang bernama The Lean and Green Supply Chain, dengan harapan dapat memperoleh peningkatan finansial dan perlindungan lingkungan, dan dengan singkat meninjau special instumen dan metode. Melalui buku panduan ini, perusahaan mendirikan sebuah mekanisme penafsiran untuk mengamati tafsiran siklus hidup, kepuasan pelanggan, dan tingkat perediaan rata-rata. Pemilihan Ecofriendly supplier adalah pemilihan supplier yang tidak hanya mempertimbangkan aspek ekonomis, namun juga telah mempertimbangkan aspek lingkungan (Lee, Kang dan Chang, 2009).

\section{Penilaian Supplier}

Melakukan penilaian dan memilih supplier merupakan salah satu tugas manajemen pengadaan. Kegiatan memilih supplier bias memakan waktu dan sumber daya yang tidak sedikit apabila supplier yang dimaksud adalah supplier kunci. Untuk supplier kunci yang berpotensi menjalin hubungan jangka panjang, proses pemilihan ini melibatkan evaluasi awal, mengundang mereka untuk berprestasi, kunjungan lapangan dan sebagainyaOleh karena itu, pemilihan supplier harus selalu dipantau performansinya melalui penilaian yang berkala. Hasil penilaian ini digunakan sebagai masukan bagi supplier untuk meningkatkan kinerja mereka.

Menurut Pujawan (2005) setiap perusahaan mempunyai kriteria yang berbeda dalam menilai supplier, tergantung dengan tujuan yang ingin dicapai oleh perusahaan. Banyak perusahaan yang melakukan kesahan fatal dalam memilih supplier. Sebagian besar perusahaan menilai supplier hanya terfokus pada harga barang, kualitas barang dan kecepatan waktu pengiriman yang diberikan tanpa melihat pengaruh ke total biaya.

\section{Pengambilan Keputusan}

Inti dari pengambilan keputusan ialah yang terletak dalam perumusan berbagai alternatif tindakan sesuai dengan yang sedang dalam perhatian dan dalam pemilihan alternatif yang tepat setelah evaluasi (penilaian) mengenai efektivitasnya dalam mencapai tujuan yang dikehendaki pengambil keputusan. Salah satu komponen terpenting dari proses pembuatan keptusan ialah kegiatan pengumpulan informasi dari mana suatu apresiasi mengenai situasi keputusan dapat dibuat. Apabila informasi yang cukup dapat dikumpulkan guna memperoleh suatu spesifikasi yang lengkap dari semua alternatif dan tingkat keefektifannya dalam situasi yang sedang menjadi perhatian proses pembuatan atau pengambilan keputusan relatif sangatlah mudah. Akan tetapi di dalam prakteknya sangat tidak mungkin untuk mengumpulkan terbatasnya dana, waktu, dan tenaga (Suprapto, 2006).

\section{Analytical Network Process (ANP)}

Analytical Network Process atau ANP adalah teori matematis yang memungkinkan seseorang pengambil keputusan menghadapi faktor - faktor yang saling berhubungan (dependence) serta umpan balik (feedback) secara sistematik. Metode ini merupakan pendekatan baru metode kualitatif yang merupakan perkembangan lanjutan dari metode terdahulu yakni Analytical Hierarchy Process (AHP) (Yulianti, 2013). Kelebihan metode ANP dari metode yang lain adalah kemampuanya untuk membantu para pengambil keputusan dalam melakukan pengukuran dan sintesis sejumlah faktor faktor dalam hierarki atau jaringan. Banyak kelebihan dari metode baru yang diperkenalkan oleh Saaty ini, yang diantaranya adalah kesederhanaan konsep yang ditawarkan. Menurut Saaty dari kesederhanaan metodenya membuat ANP menjadi metode yang lebih umum dan lebih mudah diaplikasikan untuk studi kualitatif yang beragam, seperti pengambilan keputusan, peramalah (forecasting), evaluasi, pemetaan (maaping), strategizining, alokasi sumber daya dan lain sebagainya.

ANP digunakan untuk memecahkan maslah yang bergantung pada alternatif - alternatif dan kriteria - kriteria yang ada. Dalam teknik analisisnya, ANP menggunakan perbandingan berpasangan pada alternatif - alternatif dan kriteria proyek. Pada jaringan AHP terdapat level tujuan, kriterian, subkriteria, dan alternatif dimana masing - masing level memiliki elemen. Sementara itu, level dalam AHP disebut cluster pada jaringan ANP yang dapat memiliki kriteria dan alternatif di dalamnya, yang sekarang disebut simpul. 


\section{Metode Penelitian}

Metodologi penelitian merupakan suatu prosedur yang sistematik untuk mengetahui performansi suatu project secara lebih cepat dan akurat yang digunakan sebagai pedoman dalam melakukan suatu penelitian. Tahapan dan langkah penelitian ini disajikan dalam bentuk flowchart pada gambar 1 .

\section{Hasil dan Pembahasan}

\section{Penentuan Hubungan Antar Subkriteria}

Pada tahap ini dilakukan penentuan hubungan ketergantungan antar subkriteria dalam satu kelompok (inner dependency) dan antar kelompok (outer dependency). Penentuan hubungan ketegantungan tersebut diperoleh dengan menggunakan pengisian kuesioner yang didasarkan pada penelitian Kurniawati, Yuliando, dan Widodo (2013).

Dimana jumlah responden yang terlibat dalam pengisian kuesioner penentuan hubungan antar subkriteria adalah 3 orang, sehingga apabila didalam satu sel jumlah responden yang memilih $\left(\mathrm{V}_{\mathrm{ij}}\right)$ lebih atau sama dengan Q. Dimana $\mathrm{Q}$ adalah $\mathrm{N} / 2=3 / 2=$ 1,5 (persamaan 3.1). Jika dalam suatu sel kolom tersebut jumlah responden yang memilih terdapat hubungan keterkaitan sebanyak 2 atau 3 responden, maka subkriteria tersebut dianggap adanya hubungan ketergantungan. Responden yang dipilih merupakan ahli di bagian pemilihan supplier PT. Kimia Farma plant Semarang.

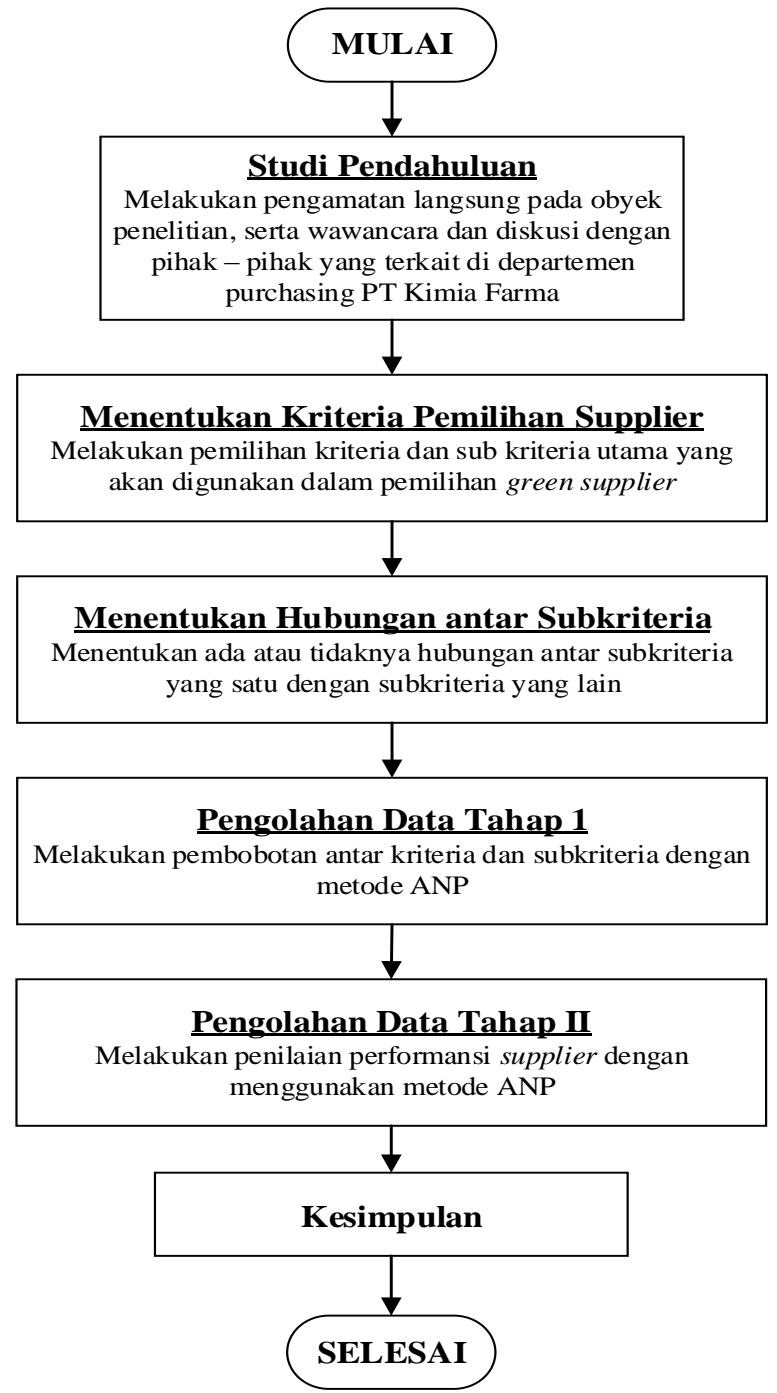

Gambar 1. Metodologi Penelitian 
Tabel 3. Rekapitulasi Kuesioner Hubungan Antar Subkriteria

\begin{tabular}{|c|c|c|c|c|c|c|c|c|c|c|c|c|c|c|c|c|c|c|c|}
\hline & \multicolumn{19}{|c|}{ Variabel Yang Dipengaruhi } \\
\hline \multirow{19}{*}{ 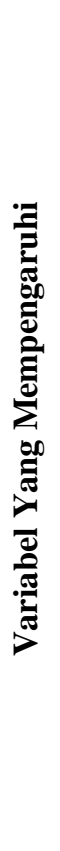 } & & Q1 & Q2 & Q3 & Q4 & C1 & $\mathrm{C} 2$ & D1 & D2 & D3 & S1 & S2 & E1 & E2 & E3 & $\mathbf{E} 4$ & E5 & R1 & R2 \\
\hline & Q1 & & 3 & & 1 & 3 & 3 & & & & & & & & & & & 1 & \\
\hline & Q2 & 3 & & & & & & & & & & & & & & & & 3 & \\
\hline & Q3 & & & & 3 & 1 & & & & & & & & & & & & 1 & \\
\hline & Q4 & 3 & 1 & & & & & 2 & & 3 & & & & & & & & 3 & \\
\hline & C1 & & & & & & 3 & & & & 1 & 1 & & & & & & 3 & \\
\hline & $\mathrm{C2}$ & & & & & & & & & 2 & & & & & & & & 1 & \\
\hline & D1 & & & & 1 & 3 & & & 3 & & & & & & & & & & \\
\hline & D2 & 1 & & & & & & & & 3 & & & & & & & & & \\
\hline & D3 & 1 & & & & & & & 2 & & & & & & & & & 1 & \\
\hline & S1 & & & & & & & & & & & & & & & & & & \\
\hline & S2 & & & & & & & & & & & & & & & & & & \\
\hline & E1 & 2 & & & & 3 & & & & & & & & & & & & & \\
\hline & E2 & 3 & & & & 1 & & 1 & & & & & & & & & & & \\
\hline & E3 & 2 & & & & 1 & & & & & & & 3 & 2 & & 3 & 3 & & \\
\hline & E4 & 3 & & & & 1 & & 1 & & & & & & & & & & & \\
\hline & E5 & & & & & & & & & & & & & & & & & & \\
\hline & R1 & 3 & & & & 2 & & & & & 2 & 3 & & & & & & & 3 \\
\hline & R2 & & & & & & & & & & 2 & & & & & & & 1 & \\
\hline
\end{tabular}

Tabel 4. Keterangan Kode Subkriteria

\begin{tabular}{cl}
\hline Kode & \multicolumn{1}{c}{ Sub Kriteria } \\
\hline Q1 & Kesesuaian Material dengan spesifikasi yang \\
Q2 & Return Rate \\
Q3 & Sertifikat terkait kualitas \\
Q4 & Garansi produk \\
C1 & Harga produk \\
C2 & Potongan Harga \\
D1 & Ketepatan waktu pengiriman \\
D2 & Lead Time \\
D3 & Jumlah pengiriman \\
S1 & Sistem Komunikasi \\
S2 & Responsif \\
E1 & Desain ramah lingkungan \\
E2 & Penggunaan bahan alam \\
E3 & Sertifikat terkait lingkungan \\
E4 & Proses produksi yang ramah lingkungan \\
E5 & Pengolahan Limbah \\
R1 & Kinerja masa lalu pemasok \\
R2 & Sistem Pembayaran \\
\hline
\end{tabular}

Penentuan Hubungan Inner Dependence dan Outer Dependence

Pada tahap selanjutnya dilakukan identifikasi adanya keterkaitan antar subkriteria, dimana pada metode Analytical Network Process (ANP) hubungan keterkaitan terbagi 2 jenis yaitu keterkaitan dalam satu set elemen (inner dependence) dan keterkaitan antar elemen yang berbeda (outer dependence). Berikut ini adalah hasil identifikasi hubungan keterkaitan antar subkriteria.

\section{Mendesain Kerangka ANP}

Berdasarkan hasil identifikasi ada atau tidak adanya hubungan keterkaitan inner dependence dan outer dependence antar subkriteria, dapat dibuat kerangka ANP berdasarkan hubungan keterkaitan antar subkriteria terkait menggunakan software super decision. Pada gambar 2 adalah kerangka ANP dengan menggunakan software super decision. 
Tabel 5. Inner dependence dan outer dependence subkriteria

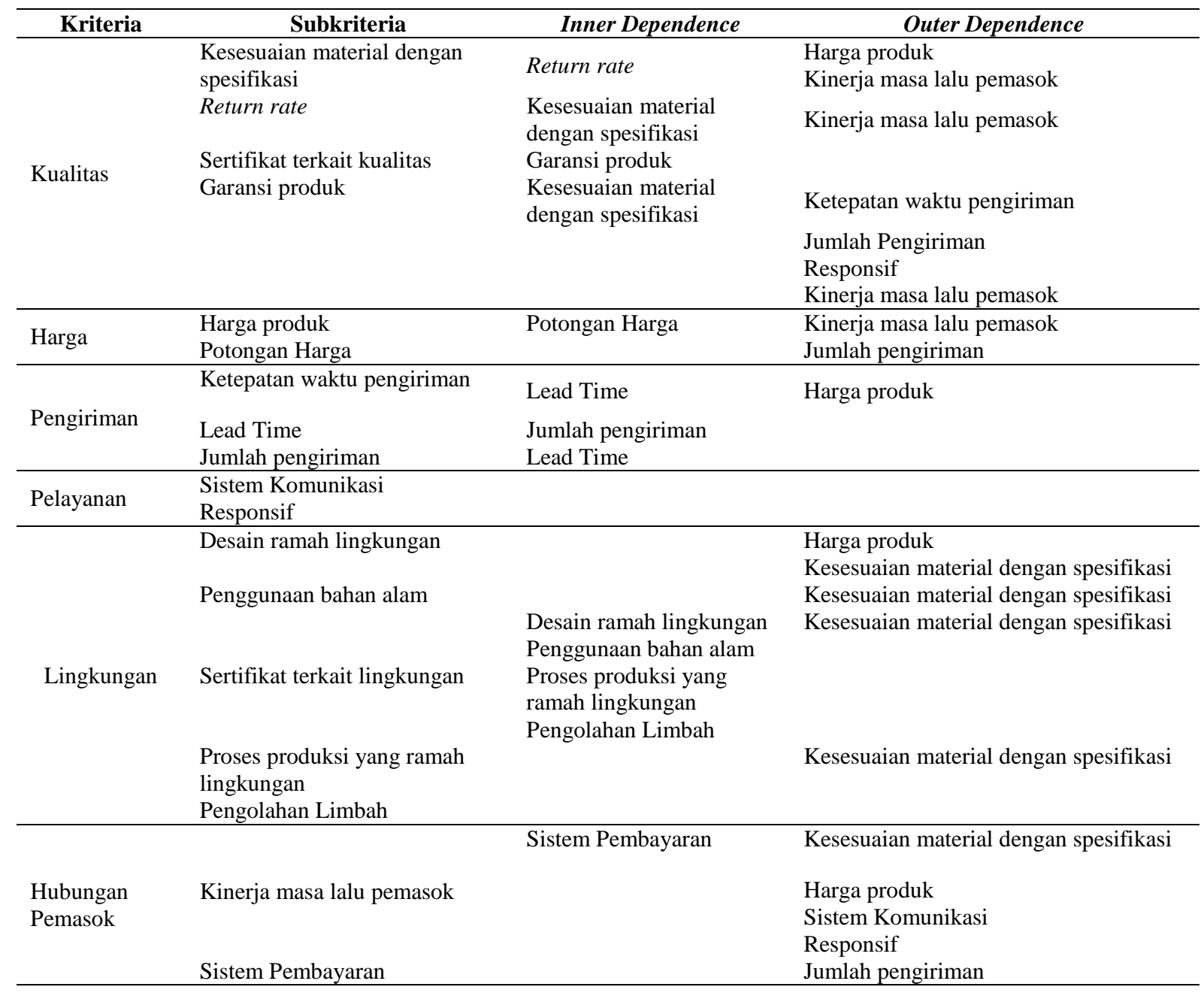

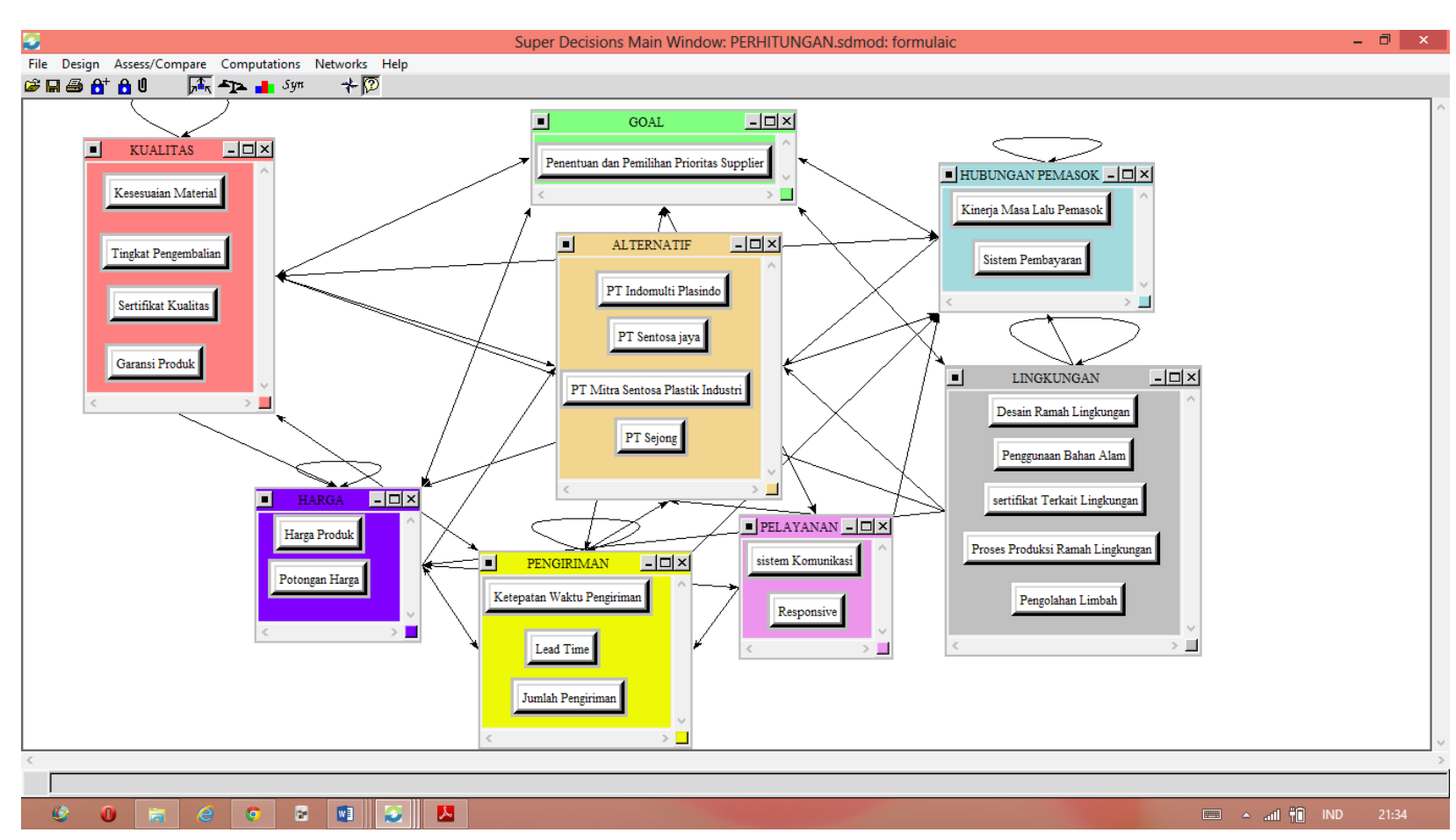

Gambar 2. Kerangka ANP 
Tabel 6. Rekapitulasi Bobot Kriteria dan Subkriteria

\begin{tabular}{|c|c|c|c|}
\hline Kriteria & $\begin{array}{c}\text { Bobot } \\
\text { kriteria }\end{array}$ & Sub Kriteria & $\begin{array}{c}\text { Bobot sub } \\
\text { Kriteria }\end{array}$ \\
\hline \multirow{4}{*}{ Kualitas } & \multirow{4}{*}{0,369} & $\begin{array}{l}\text { Kesesuaian Material dengan } \\
\text { spesifikasi yang diinginkan }\end{array}$ & 0,181 \\
\hline & & Return Rate & 0,064 \\
\hline & & Sertifikat terkait kualitas & 0,092 \\
\hline & & Garansi produk & 0,032 \\
\hline \multirow{3}{*}{ Harga } & \multirow{3}{*}{0,159} & Harga produk & 0,106 \\
\hline & & Potongan Harga & 0,053 \\
\hline & & Ketepatan waktu pengiriman & 0,058 \\
\hline \multirow[t]{2}{*}{ Pengiriman } & \multirow[t]{2}{*}{0,110} & Lead Time & 0,036 \\
\hline & & Jumlah pengiriman & 0,015 \\
\hline \multirow{2}{*}{ Pelayanan } & \multirow{2}{*}{0,072} & Sistem Komunikasi & 0,014 \\
\hline & & Responsif & 0,057 \\
\hline \multirow{5}{*}{ Lingkungan } & \multirow{5}{*}{0,246} & Desain ramah lingkungan & 0,017 \\
\hline & & Penggunaan bahan alam & 0,024 \\
\hline & & Sertifikat terkait lingkungan & 0,117 \\
\hline & & $\begin{array}{l}\text { Proses produksi yang ramah } \\
\text { lingkungan }\end{array}$ & 0,053 \\
\hline & & Pengolahan Limbah & 0,034 \\
\hline \multirow{2}{*}{$\begin{array}{l}\text { Hubungan } \\
\text { Pemasok }\end{array}$} & \multirow{2}{*}{0,044} & Kinerja masa lalu pemasok & 0,033 \\
\hline & & Sistem Pembayaran & 0,011 \\
\hline
\end{tabular}

Perhitungan Bobot Kepentingan Tiap Subkriteria

Langkah selanjutnya adalah melakukan peritungan terhadap bobot kepentingan tiap subkriteria berdasarkan hasil output software super decision. Berikut ini adalah hasil rekapitulasi output bobot kepentingan untuk setiap subkriteria.

Pada suatu survey mempresentasikan 23 kriteria yang berbeda untuk menilai evaluasi performansi supplier. Tiga Kriteria yang paling berpengaruh adalah kualitas, pengiriman dan penilaian masa lalu pemasok (Kuo dkk, 2010). Pada PT Kimia Farma plant Semarang, evaluasi supplier didasarkan pada 5 kriteria. Kualitas adalah faktor - faktor yang dapat meningkatkan kualitas produk yang berasal dari supplier (Lee, Kang dan Chang, 2009). Kriteria Kualitas memiliki bobot paling besar diantara seluruh kriteria yang ada yakni sebesar 0,369 yang dilanjutkan dengan kriteria lingkungan dengan bobot sebesar 0,246. Manajemen lingkungan adalah faktor - faktor yang menunjukkan usaha dari supplier untuk melakukan manajemen lingkungan (Lee, Kang dan Chang, 2009). Kriteria ketiga adalah kriteria biaya dengan bobot sebesar 0,159, kriteria pengiriman dengan bobot sebesar 0,11 , kriteria pelayanan dengan bobot sebesar 0,072 , dan yang paling kecil bobotnya adalah pada kriteria hubungan pemasok yaitu dengan bobot sebesar 0,044. Hal ini menunjukkan bahwa walaupun PT Kimia Farma plant Semarang sudah mulai menerapkan konsep eco friendly namun dalam kriteria pemilihan supplier PT Kimia Farma masih mengedepankan kualitas produk. Kriteria lingkungan sebagai aspek ramah lingkungan berada pada urutan kedua setelah kualitas. Hal tersebut berarti bahwa aspek lingkungan supplier juga dipertimbangkan oleh PT Kimia Farma plant Semarang dalam menentukan

Jurnal Teknik Industri, Vol. XI, No. 1, Januari 2016 pemilihan supplier. Perusahaan diharapkan untuk mengadakan material - material dari supplier yang ramah lingkungan dan juga memilih supplier yang juga telah mempertimbangkan dan peduli terhadap lingkunganya (Kuo dkk, 2010).

\section{Rekomendasi Supplier Terbaik}

Pada bagian ini merupakan tahapan untuk mengetahui nilai dari performansi aktual para supplier. Supplier yang dinilai adalah 4 supplier kontainer terbaik. Pengolahan data dilakukan dengan metode ANP dengan menggunakan software super decision.

Tabel 7. Rekapitulasi Performansi Supplier terhadap Masing - Masing Kriteria

\begin{tabular}{lcccc}
\hline Kriteria & $\begin{array}{c}\text { PT } \\
\text { Indomulti } \\
\text { Plasindo }\end{array}$ & $\begin{array}{c}\text { PT } \\
\text { Sentosa } \\
\text { Jaya }\end{array}$ & $\begin{array}{c}\text { PT } \\
\text { Mitra } \\
\text { Pentosa } \\
\text { Plastik }\end{array}$ & $\begin{array}{c}\text { PT } \\
\text { Sejong }\end{array}$ \\
\hline Kualitas & 0,13357 & 0,09334 & 0,04133 & 0,0950 \\
Harga & 0,04219 & 0,05715 & 0,03989 & 0,07086 \\
Pengiriman & 0,01504 & 0,02220 & 0,01739 & 0,02313 \\
Pelayanan & 0,00540 & 0,02220 & 0,00557 & 0,00215 \\
$\begin{array}{l}\text { Lingkungan } \\
\text { Hubungan } \\
\text { Pemasok }\end{array}$ & 0,04074 & 0,0578 & 0,02356 & 0,07805 \\
\hline Jumlah & 0,00421 & 0,00224 & 0,00687 & 0,00213 \\
\hline
\end{tabular}

Berdasarkan nilai performansi pada keenam kriteria pemilihan supplier ramah lingkungan didapatkan urutan rekomendasi supplier yakni PT Sejong dengan total score sebesar 27,132\%, PT 
Sentosa Jaya dengan score sebesar 25,291\%, PT Indomulti Plasindo sebesar 24,116\%, dan PT Mitra Sentosa Plastik Industri sebesar 23,461\%.

\section{Kesimpulan}

Dalam menentukan pemilihan ramah lingkungan supplier terdapat 6 kriteria dan 18 sub kriteria. Kriteria yang pertama adalah kualitas, dimana di dalam kriteria kualitas terdapat 4 sub kriteria yaitu kesesuaian material dengan spesifikasi yang diinginkan, return rate atau tingkat pengembalian, sertifikat terkait kualitas, dan garansi produk. Didalam kriteria harga terdapat dua subkriteria yaitu harga penawaran dan potongan harga. Kriteria pengiriman terdapat tiga subkriteria yaitu ketepatan waktu pengiriman lead time, dan jumlah pengiriman. Kriteria pelayanan terdapat dua subkriteria yaitu responsif atau kecepatan supplier dalam menanggapi komplain dan kemudahan komunikasi. Kriteria lingkungan merupakan kriteria ramah lingkungan dalam pemilihan supplier. Pada kriteria lingkungan terdapat 5 subkriteria yaitu desain ramah lingkungan, penggunaan bahan alam, sertifikat terkait lingkungan, proses produksi yang ramah lingkungan, dan pengolahan limbah. Kriteria yang terakhir adalah hubungan pemasok yang terdiri dari dua subkriteria yaitu kinerja masa lalu pemasok dan sistem pembayaran.

Pemilihan supplier ramah lingkungan dibedakan atas 6 kriteria dan 18 subkriteria yang dilakukan pembobotan untuk masing masing kriteria dan subkriteria tersebut. Kriteria kualitas memiliki bobot sebesar 0,369. Kriteria lingkingan memiliki bobot sebesar 0,246. Kriteria harga memiliki bobot sebesar 0,159 . Kriteria pengiriman memiliki bobot sebesar 0,085 Kriteria pelayanan memiliki bobot sebesar 0,072 . Kriteria hubungan pemasok memiliki bobot sebesar 0,044. Untuk itu perusahaan supplier harus lebih memperhatikan kriteria - kriteria yang menjadi fokus PT Kimia Farma plant Semarang dengan urutan kriteria kualitas, lingkungan, harga, pengiriman, pelayanan, dan hubungan pemasok.

Pada pengolahan data telah dilakukan mengenai penilaian performansi supplier yang memenuhi kriteria supplier ramah lingkungan. Penilaian performansi supplier tersebut dilakukan dengan metode ANP dengan menggunakan software super decision. Penilaian performansi dilakukan pada 4 supplier yaitu PT Indomulti Plasindo, PT Sentosa Jaya, PT Mitra Sentosa Plastik Mandiri, dan PT Sejong. Penilaian terhadap keempat supplier tersebut menghasilkan urutan rekomendasi ecofriendly supplier yaitu PT Sejong dengan skor 0,27132, PT sentosa Jaya dengan skor 0,25291, PT Indomulti Plasindo dengan skor 0,24116, dan PT Mitra Sentosa Plastik Industri dengan skor 0,23461.

\section{Daftar Pustaka}

Amin, S.H., Zhang, G. 2012. An Integrated Model for Closed Loop Supply Chain Configuration and Supplier Selection: Multi Objective Approach. Expert system application. 39. 6782-6791.

Ferraro, Carla. 2009. The Green Consumer. Monash University.

Ghoddsypour, S.H., dan O'Brien C. 2001 The Total Cost of Logistic in Supplier Selection, under Conditions of Multiple Sourching, Multiple Criteria and Capacity Constrains. International Journal of Production Economics, 73, 15-27.

Gilbert, S. (2000). Greening supply chain: Enhancing competitiveness through green productivity. Report of the Top Forum on Enhancing Competitiveness through Green Productivity held in the Republic of China, 25-27 May, 2000. ISBN: 92-833-2290-8.

Kainuma, Y., \& Tawara, N. 2006. A Multiple Attribute Utility Theory Approach to Lean and Green Supply Chain Management. International Journal of Production Economics, 101(1), 99108.

Kuo, R.J., Wang, Y.C. Tien, F. C., 2010. Integration of Artificial Neural Network and MADA methods for Green Supplier Selection. Journal of Cleaner Production,18,1161-1170.

Kurniawati, Dewi., Yuliando, Henry., Widodo, Kuncoro. 2013. Kriteria Pemilihan Pemasok Menggunakan Analytical Network Process. Jurnal Teknik Industri (ISSN) 15(1), 24-32.

Lee, A.H.I., Kang, H.Y., Chang, C.T., 2009. A Green Supplier Selection Model for high-tech Industry. Expert system with application.

Penfield, Patrick. 2007. The Green Supply Chain. Material Handling Industry of America.

Pujawan I. Nyoman. 2005. Supply Chain Management. Surabaya : Guna Widya.

Samadhan, Deshmukh. Sunnapwar, Viviek. 2013. Validation of Performance Measures for Green Supplier Selection in Indian Industries. International Journal of Modern Engineering Research (IJMER). 3(3), 1617 - 1622.

Suprapto, Johanes. 2006. Riset Operasi (Untuk Mengambil Keputusan). Jakarta : Penerbit Universitas Indonesia.

Vachon, S., \& Klassen, R. D. 2006. Green Perfect Partnership in the Supply Chain : The case of the package printing industry. Journal of Cleaner Production, 14(6-7), 661-671.

Vanany, Iwan. 2003. Aplikasi Analytic Network Process (ANP) pada Perancangan Sistem Pengukuran Kinerja (Studi Kasus Pada PT. X). Jurnal Teknik Industri Vol. 5, No. 1, Juni 2003.

Yulianti, Mega. 2013. Penerapan Metode ANP dan TOPSIS Dalam Pemilihan Supplier. UPI. 